ఠ

\title{
miR-195 is a key regulator of Rafl in thyroid cancer
}

\author{
Fangzheng Wang ${ }^{1,2, *}$ \\ Chuner Jiang $g^{3, *}$ \\ Quanquan Sun ${ }^{1,2}$ \\ Fenqin Yan ${ }^{1,2}$ \\ Lei Wang ${ }^{1,2}$ \\ Zhenfu Fu ${ }^{1,2}$ \\ Tongxin Liu ${ }^{1,2}$ \\ Fujun $\mathrm{Hu}^{1,2}$ \\ 'Department of Radiation Oncology, \\ Zhejiang Cancer Hospital, ${ }^{2}$ Zhejiang \\ Key Laboratory of Radiation \\ Oncology, Zhejiang Cancer Hospital, \\ ${ }^{3}$ Department of Breast Surgery, \\ Zhejiang Cancer Hospital, Zhejiang, \\ Hangzhou, People's Republic of China \\ *These authors contributed equally \\ to this work
}

This article was published in the following Dove Press journal:

OncoTargets and Therapy

20 October 2015

Number of times this article has been viewed

\begin{abstract}
Proto-oncogene Rafl serves as a part of the mitogen-activated protein kinases/extracellular signal-regulated kinase signal transduction pathway and regulates cell migration, apoptosis, and differentiation. Although a large number of studies have shown that Raf1 is overexpressed in various kinds of cancer, little is known about the association between Raf1 and miRNAs in thyroid carcinoma. This study proves that Raf1 is overexpressed in thyroid cancer, which has been confirmed by many other studies. Besides, we identify that Raf1 is a direct target of miR-15a/b, miR-16, and miR-195 by dual luciferase reporter assay. We also find that the expression of miR-195 is downregulated in 50 pairs of thyroid tumor tissues compared to the adjacent nontumor tissues, while there is no difference in the expression of $\mathrm{miR}-15 \mathrm{a} / \mathrm{b}$ and miR-16 between the groups. Furthermore, exogenous overexpression of miR-195 significantly inhibits the protein expression of Raf1 and blocks the thyroid cancer cell proliferation. Our findings delineate a novel mechanism for the regulation of Rafl in thyroid cancer, which may help to provide a new direction for the treatment of thyroid cancer.
\end{abstract}

Keywords: Raf1, microRNA, thyroid cancer, proliferation

\section{Introduction}

The incidence of thyroid cancer is increasing rapidly in recent years, ${ }^{1}$ making it the most common endocrine relevant tumor. ${ }^{2}$ There are four major types of thyroid cancer: papillary, follicular, medullary, and anaplastic. Thyroid cancer is three times more common in women than in men. Although the risk factors that have been identified for thyroid cancer include a family history of goiter, exposure to high levels of radiation, and certain hereditary syndromes, the cause of thyroid cancer is still unclear.

miRNA is a small noncoding RNA molecule that plays a key role in posttranscriptional regulation of gene and RNA silencing. ${ }^{3,4}$ Disorder of miRNAs is involved in the development of diverse tumors. ${ }^{5,6}$ The circulating miRNAs have been identified as specific biomarkers for the diagnosis of various cancers, such as lung cancer, ${ }^{7,8}$ kidney diseases, ${ }^{9}$ breast cancer, ${ }^{10}$ hematologic cancer, ${ }^{11}$ prostate cancer, ${ }^{12}$ and thyroid cancer. ${ }^{13}$ Results from miRNA microassays reveal that miRNAs including miR-146, miR-221, miR-222, and miR181 are upregulated in thyroid cancer, whereas miRNAs including miR-15, miR-551, miR873, miR-876, and miR-203 are significantly deregulated in thyroid cancer. ${ }^{14,15}$

miR-15a/b, miR-16, and miR-195 are the members of the miR-15 family. A study by Calin et al found that miR-15 and miR-16 are downregulated or deleted in $68 \%$ of chronic lymphocytic leukemia. ${ }^{16}$ Besides, miR-15a/16-1 deletion can accelerate the proliferation of B-cells by regulating the expression of genes associated with cell cycle. ${ }^{17}$ miR-15a/16-1 can also repress the expression of oncogene $B C L-2 .{ }^{18}$ Recent studies 
reveal that exogenous miR-195 transfection can inhibit the proliferation of colorectal cancer cells ${ }^{19}$ and hepatocellular carcinoma cells. ${ }^{20}$ Rescuing the expression of miR-195 in breast cancer cells significantly inhibits cell survival and promotes cellular apoptosis. ${ }^{21}$

As a proto-oncogene, Raf1 is an effector of RAS that is activated by many growth factors ${ }^{22}$ and guides the receptor signals from cell membrane to nucleus. ${ }^{23}$ Once activated, Rafl phosphorylates and activates Raf-MEK-ERK pathway, which then regulates cell cycle, proliferation, apoptosis, and migration. ${ }^{24-26}$ Although massive studies have shown that Raf1 is overexpressed in various kinds of cancers, the mechanism for the regulation of Rafl by miRNA is indistinct.

In this study, we show for the first time that Raf1 is upregulated in thyroid cancer and identified that Raf1 is a target gene of miR-15a/b, miR-16, and miR-195. We also demonstrate miR-195 is downregulated in thyroid cancer, while there is no difference in the expression of miR-15a/b and miR-16. Overexpression of miR-195 markedly suppresses the growth of thyroid cancer cells. This study reveals a novel negative regulatory mechanism of Raf1, which can provide us a new direction for thyroid cancer therapy.

\section{Materials and methods Clinical samples}

A total of 50 matched neoplastic and normal human thyroid tissues are obtained from surgical specimens and immediately frozen in $-80^{\circ} \mathrm{C}$. Thyroid tumors are collected from patients undergoing surgical resections from 2011 to 2014 in the Zhejiang Cancer Hospital. All patients have a clear histologic diagnosis of thyroid cancer based on the American Joint Committee on Cancer. Every sample enrolled in this study is obtained with the patients' informed consent, and the study protocol is approved by the Medical Ethics and Human Clinical Trial Committee.

\section{Cell culture and transfection}

Human thyroid cancer cell lines B-CPAP and ACT-1 are cultured in 1640 medium supplemented with $10 \%$ fetal calf serum, $100 \mathrm{U} / \mathrm{mL}$ penicillin, and $100 \mathrm{U} / \mathrm{mL}$ streptomycin at $37^{\circ} \mathrm{C}$ in $5 \% \mathrm{CO}_{2}$ incubator.

miR-195 overexpressing stable cell line (LV-miR-195) and negative control stable cell line (LV-NC) are generated by infecting with Lentivirus-packaged pre-miR-195 according to standard protocols as recommended by the manufacturer (GeneChem, Shanghai, People's Republic of China). The expression of miR-195 in stable cell lines is identified by real-time polymerase chain reaction (PCR) assay.

\section{RNA isolation and quantitative real-time PCR}

Total RNA in cultured cells is extracted using Trizol Reagent (Thermo Fisher Scientific, Waltham, MA, USA), then miRNA is purified with the miRVana miRNA Isolation Kit (Thermo Fisher Scientific, Waltham, MA, USA). cDNA is synthesized using the PrimeScript ${ }^{\mathrm{TM}}$ RT Reagent Kit (Takara, People's Republic of China). Stem-Loop RT-PCR assay is used to detect the expression of miR-15, miR-16, and miR-195 as described earlier. ${ }^{27}$ The expression of Rafl is assessed using the following primers: Raf1-forward, 5'-GGGAGCTTGGAAGACGATCAG-3'; Raf1-reverse, 5'-ACACGGATAGTGTTGCTTGTC-3'; glyceraldehyde-3-phosphate dehydrogenase (GAPDH)forward, 5'-CTGGGCTACACTGAGCACC-3'; GAPDHreverse, 5'-AAGTGGTCGTTGAGGGCAATG-3'. All the quantitations of PCR data are performed according to the method described earlier. ${ }^{28}$

\section{Western blot analysis}

Cells are lysed in radio-immunoprecipitation assay lysis buffer supplemented with protease inhibitor mixture, and the protein concentration is quantified using an Enhanced BCA Protein Assay kit (Beyotime). A $30 \mu \mathrm{g}$ of total protein extract is separated by $8 \%$ sodium dodecyl sulfate polyacrylamide gel electrophoresis and transferred to a polyvinylidene difluoride membrane (EMD Millipore, Billerica, MA, USA). After blocking with 5\% nonfat dry milk, the samples are incubated with mouse anti-GAPDH monoclonal antibody (KangChen Biotech, Shanghai, People's Republic of China) and rabbit antiRaf1 monoclonal antibody (Abcam, Cambridgeshire, UK).

\section{Cell count assay}

In a 6-well plate, $1 \times 10^{5} \mathrm{LV}$-NC or LV-miR-195 Lentivirusinfected cells are seeded. Cells are harvested and counted every day after seeding. Each point of the growth curve is the average of triplicates.

\section{Dual luciferase reporter assay}

The Raf1 3'-untranslated region (3'-UTR) is amplified and cloned into the pmiR-REPORT ${ }^{\mathrm{TM}}$ vector (Thermo Fisher Scientific, Waltham, MA, USA). B-CPAP and ACT-1 cells are seeded in 24-well plate and cotransfected with $100 \mathrm{ng}$ wild-type (WT) or deletion reporter vector and $10 \mathrm{ng}$ pmiR-REPORT ${ }^{\text {TM}}-\beta$ gal control plasmid in the presence of $100 \mathrm{nM}$ either miR-15a/b, miR-16, miR-195 mimics, or negative control mimics. After 36 hours, the luciferase activity is measured using the Dual Luciferase Reporter Assay System (Promega Corporation, Fitchburg, WI, USA). All experiments are performed independently in triplicate. 


\section{Immunohistochemistry staining}

Immunohistochemistry (IHC) staining is performed using UltraSensitive $^{\text {TM }}$ S-P kit (MAIXIN-BIO, Fuzhou, People's Republic of China). Formalin-fixed, paraffin-embedded thyroid cancer tissue slides are heated (high pressure, 100 seconds) for antigen retrieval with citrate buffer $(\mathrm{pH}=6.0)$ as the solution. Endogenous peroxidase activity is blocked by $3 \%$ hydrogen peroxide. Slides are incubated with rabbit anti-Raf1 monoclonal (Abcam, 1:100) after blocking with goat serum. Finally, the slides are immunostained with UltraSensitive $^{\text {TM }}$ S-P kit (Rabbit, MAIXIN-BIO) and DAB Detection kit (MAIXIN-BIO).

\section{Bioinformatics analysis}

TargetScan software (Whitehead Institute for Biomedical Research, Boston, USA) is used to analysis the $3^{\prime} \mathrm{UTR}$ of Raf1.

\section{Statistical analysis}

All data are analyzed by Statistical SPSS Version 17.0 (IBM, Chicago, USA). Differences between two groups are estimated with paired $t$-test (two tail), and the data are expressed as mean \pm standard deviation. For all the tests, differences with $P<0.05$ are considered statistically significant.

\section{Results \\ Rafl protein level is elevated in thyroid cancer}

The protein level of Raf1 is determined by immunohistochemical staining using a Raf1 monoclonal antibody. As shown in Figure 1, Raf1 is overexpressed in thyroid cancer tissue (right) compared to matched normal thyroid tissues (left). Both tumor and normal thyroid tissues are dissected from the same patient. The results show that thyroid cancer has a higher level expression of Rafl compared to the adjacent tissues.

\section{The potential miRNAs targeting Rafl 3'UTR}

miRNAs can repress the expression of target gene by binding to the complementary sequences of the target gene messenger RNA (mRNA) 3'UTR. miRNAs can serve as tumor suppressors or oncogenes in tumors, and their abnormal expressions are associated with the development and progression of cancer. ${ }^{29}$ So, we analyze the 3 'UTR of Raf1 by bioinformatics analysis to identify potential binding miRNAs. Figure 2 shows that miR-15 clusters, miR-19, miR-125 clusters, and miR-7 may be the potential miRNAs that can interact with Raf1 3'UTR.
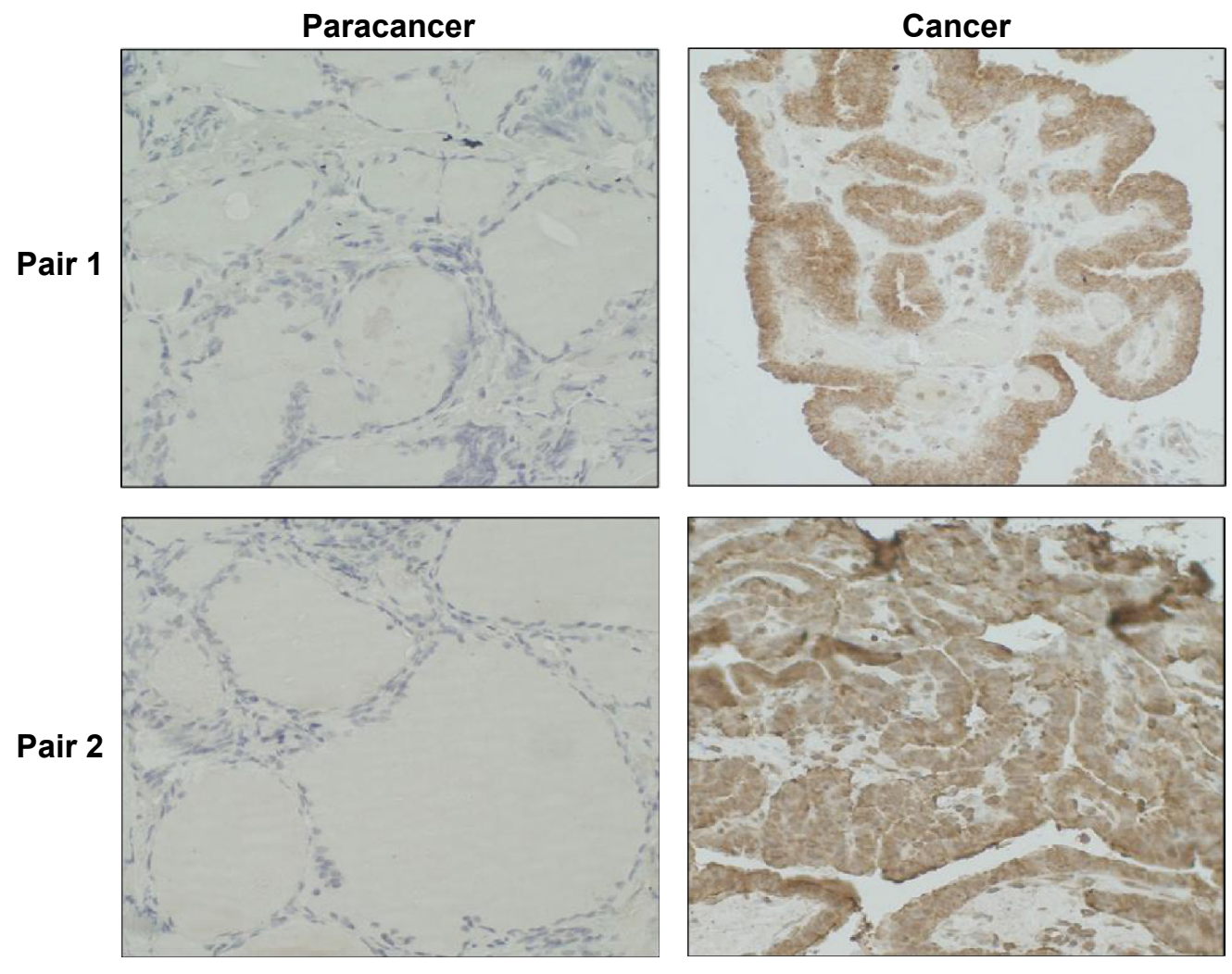

Figure I Rafl protein level is elevated in thyroid cancer.

Note: Immunohistochemical staining analysis of Rafl expression in paracancer and cancer tissues. 
Human Raf1 3'UTR

$\begin{array}{llllll}\text { Gene } & \\ \text { Human Raf1 NM_002880 3'UTR length: } 913 & & & & & \end{array}$

\section{Conserved sites for miRNA families broadly conserved among vertebrates}

$\begin{array}{llc}\operatorname{miR}-15 a b c / 16 / 16 a b c / 195 / 322 / 424 / 497 / 1907 & \operatorname{miR}-19 a b & \operatorname{miR}-125 a-5 p / 125 b-5 p / 351 / 670 / 4319 \\ \operatorname{miR}-503 & \operatorname{miR}-455-5 p & \operatorname{miR}-7 / 7 a b \\ & & \operatorname{miR}-7 / 7 a b\end{array}$

Figure 2 The potential miRNAs targeting RafI 3'UTR.

Note: The 3'UTR of RafI mRNA is analyzed by TargetScan software.

Abbreviations: mRNA, messenger RNA; miRNA, microRNA; UTR, untranslated region.

\section{Rafl is a target gene of miR-I5a/b,} miR-16, and miR-195 in thyroid cancer cells Among these potential miRNAs, we focus our attention on miR-15 family, which is known as tumor suppressor. To further confirm this hypothesis, luciferase reporter vectors containing the predicted seed sequences in the $3^{\prime} \mathrm{UTR}$ of Raf1 (WT-UTR) and the deletion Raf1 3'UTR clone (deletion-UTR) that has a 12-nucleotide deletion in the common binding sites of miR-15a/b, miR-16, and miR-195 are constructed (Figure 3A). From the results, we can find that $\mathrm{miR}-15 \mathrm{a} / \mathrm{b}$, miR-16, and miR-195 mimics can repress the luciferase activity of Raf1-WT-UTR compared to control mimics. While there is no significant difference when cotransfected with the Raf1 deletion UTR (Figure 3B-D), indicating $\mathrm{miR}-15 \mathrm{a} / \mathrm{b}$, miR-16, and miR-195 can directly bind to the 3 '-UTR of Raf1 mRNA.

\section{miR-I 95 is downregulated in thyroid cancer tissues}

The expression of miR-15a/b, miR-16, and miR-195 in 50 paired thyroid tumor tissue samples is measured by real-time PCR. As shown in Figure 4C, miR-195 is significantly

\section{A}

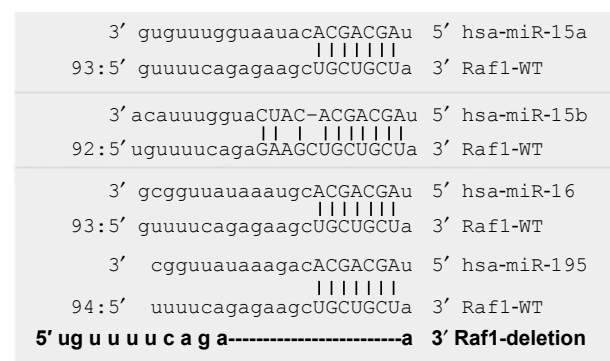

C

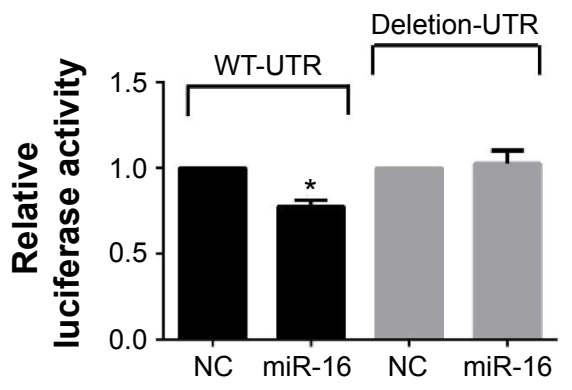

B
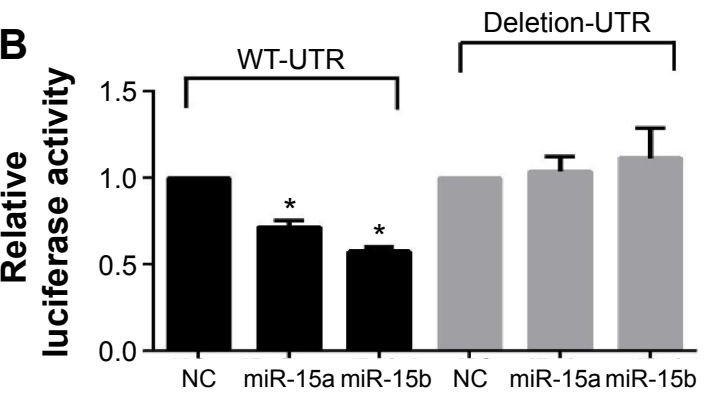

D

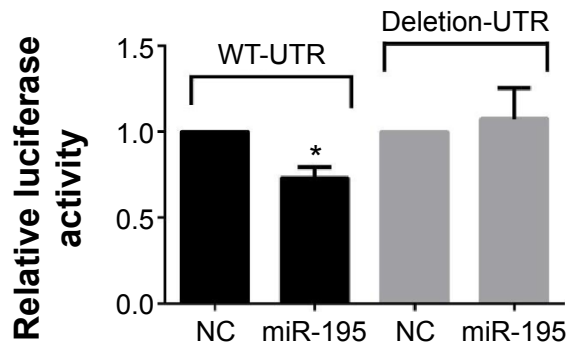

Figure $3 \mathrm{Rafl}$ is a direct target of miR-15a/b, miR-16, and miR-195.

Notes: (A) A putative miR-15a/b, miR-16, and miR-195-binding site in the 3'UTR of Rafl mRNA is shown, sequences of WT-UTR and deletion-UTR are listed. (B) The luciferase activity is measured when cotransfected miR-15a/b with WT-UTR or deletion-UTR. (C) The luciferase activity is measured when cotransfected miR-I6 with WT-UTR or deletion-UTR. (D) The luciferase activity is measured when cotransfected miR-195 with WT-UTR or deletion-UTR. Data used are the mean values taken from three independent experiments. Data are expressed as mean $\pm S D(* P<0.05)$.

Abbreviations: mRNA, messenger RNA; SD, standard deviation; UTR, untranslated region; WT, wild-type; NC, negative control. 
downregulated in tumor tissues compared to matched normal tissues $(P<0.05)$. While the expression of miR-15a/b and miR-16 in cancer tissues is similar to the noncancerous tissues (Figure 4A and B). These results suggest miR-195 rather than $\mathrm{miR}-15 \mathrm{a} / \mathrm{b}$ or miR-16 may be the key upstream miRNA of Rafl in thyroid cancer.

\section{Rafl is a direct target of miR-195 in thyroid cancer cells}

To further determine if Raf1 is a target gene of miR-195 in thyroid cancer, protein and mRNA levels of Rafl are checked in B-CPAP and ACT-1 overexpressing stable cell lines. As shown in Figure 5A, recovering the expression of miR-195 significantly represses Raf1 protein expression. However, there is no marked difference between the Rafl mRNA level in control group and miR-195 overexpressing group (Figure 5B). These data indicate that Raf1 is a direct target of miR-195 in thyroid cancer cells, and miR-195 can regulate the expression of Rafl by inhibiting protein translation. The transfection efficiency is confirmed by real-time PCR. We can find the expression of miR-195 is significantly increased in the overexpressing stable cell lines (Figure 5C).
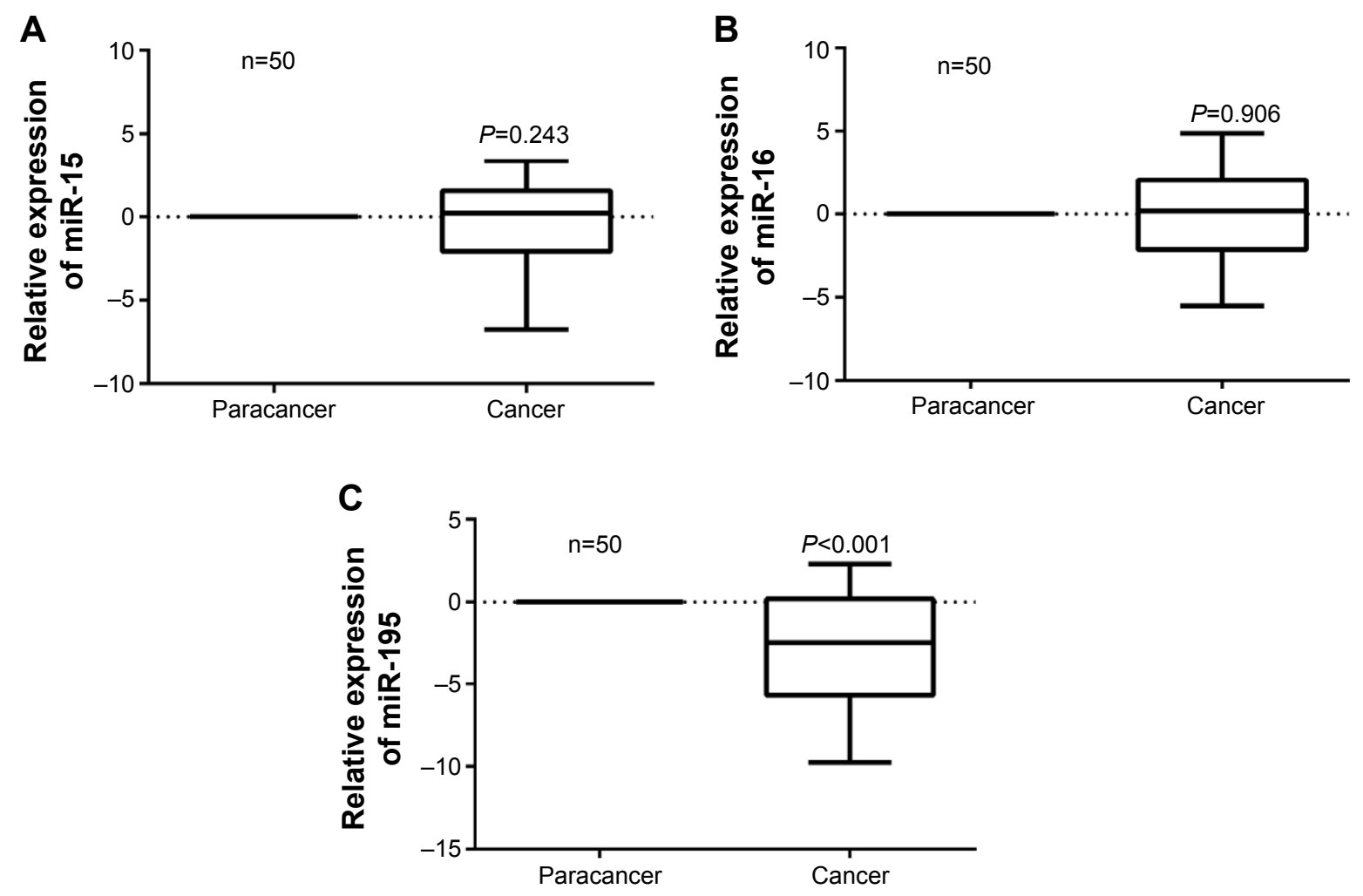

Figure 4 miR-195 is downregulated in thyroid cancer tissues.

Notes: (A) RNA expression analysis of miR-15 in thyroid cancer $(n=50)$. (B) RNA expression analysis of miR-16 in thyroid cancer ( $n=50)$. (C) RNA expression analysis of miR- 195 in thyroid cancer $(n=50)$. 
A

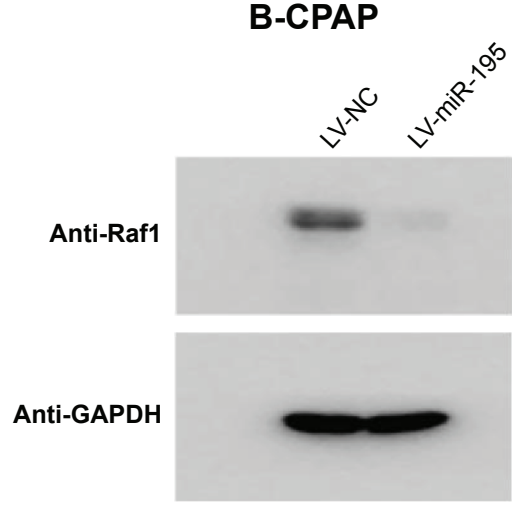

B

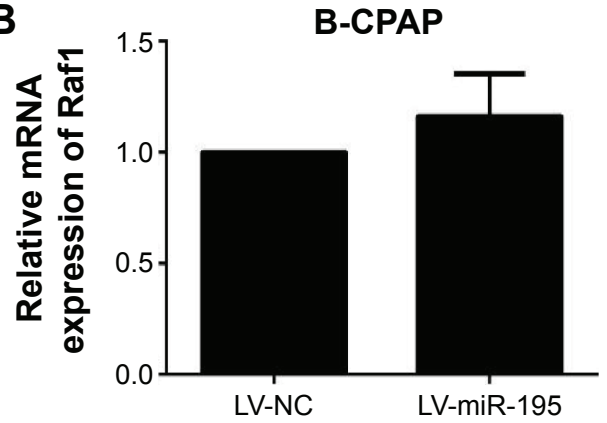

C

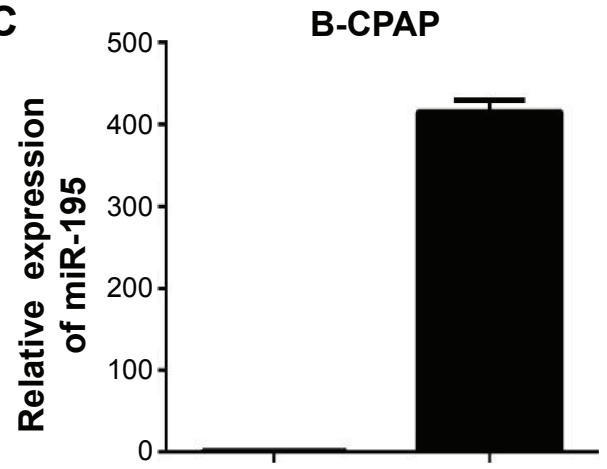

ACT-1

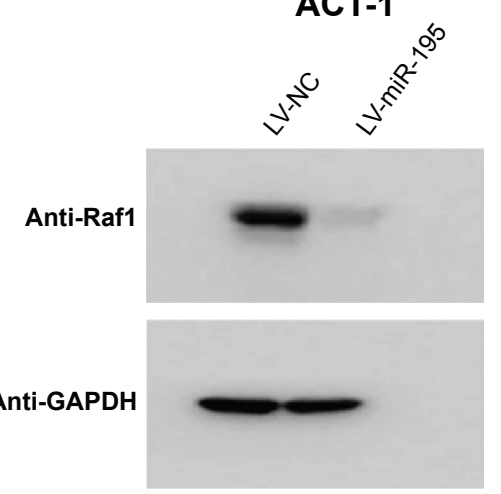

ACT-1

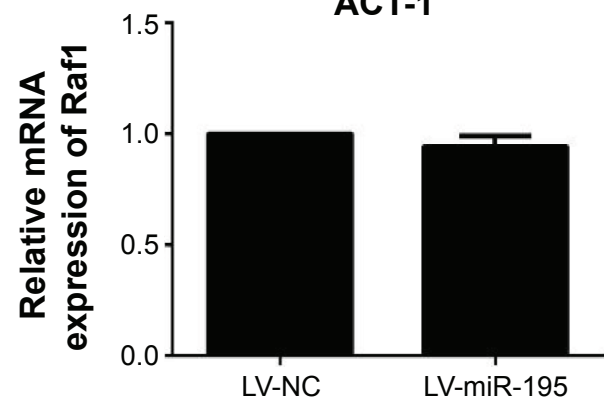

ACT-1

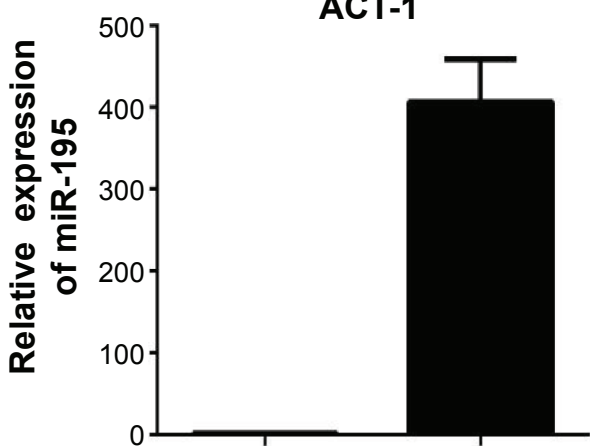

Figure 5 Rafl is a direct target of miR-195 in thyroid cancer cells.

Notes: (A) Protein expression of Rafl in B-CPAP and ACT-I is detected by Western blot analysis. (B) mRNA expression of Rafl in B-CPAP and ACT-I is detected by real-time PCR. (C) The expression levels of miR- 195 in B-CPAP and ACT-I stable cell lines are checked by real-time PCR.

Abbreviations: mRNA, messenger RNA; PCR, polymerase chain reaction; GAPDH, glyceraldehyde-3-phosphate dehydrogenase; NC, negative control; LV, lentivirus.
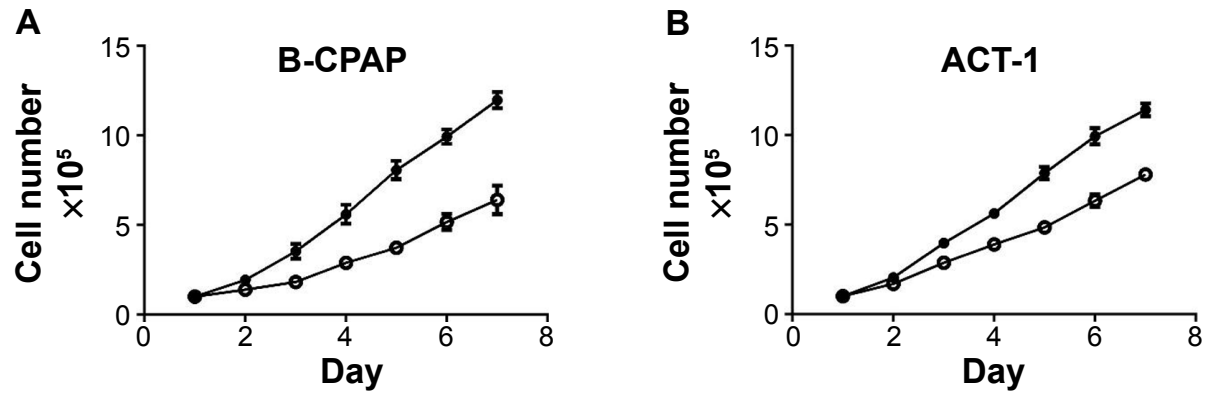

LV-NC LV-miR-195

Figure 6 Overexpression of miR-195 inhibits cell proliferation.

Notes: (A) Growth curve by counting cell number in B-CPAP overexpression stable cell lines. (B) Growth curve by counting cell number in ACT-I overexpression stable cell lines. Cell amounts in each sample is measured daily in triplicates, and three independent experiments are performed. Data are expressed as mean \pm SD.

Abbreviations: SD, standard deviation; NC, negative control; LV, lentivirus. 
In the direct downstream of RAS, Rafl can be activated by RAS and promotes the activation of the downstream signaling cascade RAF/MEK/ERK, which is important in the regulation of cell proliferation, apoptosis, and differentiation. ${ }^{33}$ In the present study, we find that thyroid cancer tissues have higher Raf1 expression compared to the adjacent tissues (Figure 1).

By inhibiting or degrading the target mRNA, miRNAs play a key role in the posttranscriptional regulation of the target gene. ${ }^{34}$ A large number of studies have proved that dysregulation of miRNAs has close correlations with the progress of thyroid cancer. Overexpression of miRNAs, such as miR-146 and miR-34a, in thyroid cancer promote cell proliferation. ${ }^{35,36}$ While miR-204, miR-181, and miR-101, which are deregulated in thyroid cancer, can suppress cancer proliferation and metastasis. ${ }^{37}$ A somatic Raf1 mutation occurs in $\sim 40 \%-60 \%$ of papillary thyroid cancer, which makes the design of targeted drug more difficult. However, the characters that both the WT and the mutation type of Rafl share a same 3'UTR pushes drugs based on miRNA more striking. Bioinformatic analysis of Raf1 3'UTR reveals that miR-15 clusters may be the key potential miRNAs, which stand in the key regulation cross Rafl (Figure 2). Further luciferase report assay confirms that Raf1 is a target gene of miR-15a/b, miR-16, and miR-195 (Figure 3).

Prostate tumor xenografts demonstrate that overexpression of miR-15a and miR-16 can induce growth arrest and promotes apoptosis. ${ }^{38}$ In this study, the level of $\mathrm{miR}-15 \mathrm{a} / \mathrm{b}$ and miR-16 in 50 pairs of thyroid cacner tissues is detected. However, the expression of miR-15a/b and miR-16 in cancer tissues displays a similar expression as noncancer tissues (Figure 4A and B). miR-195, another member of miR-15 clusters, is decreased in colon cancer, ${ }^{39}$ gastric cancer, ${ }^{40}$ breast cancer, ${ }^{41}$ hepatocellular carcinoma, ${ }^{42}$ bladder cancer, ${ }^{43}$ and non-small-cell lung cancer. ${ }^{44-46}$ Regaining the level of miR-195 in lung cancer cell inhibits cell proliferation and metastasis by targeting HDGF and IGF1R. ${ }^{47,48}$ Recent studies reveal that miR-195 is involved in triple-negative breast cancer and the drug sensitivity of breast cancer. ${ }^{49,50}$ Herein, we find that miR-195 is downregulated in thyroid cancer (Figure 4C). We also confirm that miR-195 can repress the protein expression rather than the mRNA expression of Raf1 by interacting with the 3'UTR of Raf1 mRNA (Figures 3D and 5). These findings indicate that the regulation of Raf1 by miR-195 is mostly through protein translation inhibition rather than the degradation of mRNA.

\section{Conclusion}

In this study, we identify that Rafl is overexpressed in thyroid cancer, which may be mainly caused by the deregulation of
miR-195. Meanwhile, we confirm that miR-195 can inhibit the proliferation of thyroid cancer cells. Taken together, our data reveal a novel mechanism for the regulation of Raf1 in thyroid cancer, which may facilitate the advancement of clinical diagnosis, treatment, and prevention in thyroid cancer.

\section{Disclosure}

The authors report no conflicts of interest in this work.

\section{References}

1. Carling T, Udelsman R. Thyroid cancer. Annu Rev Med. 2014;65: 125-137.

2. Marotta V, Sciammarella C, Vitale M, Colao A, Faggiano A. The evolving field of kinase inhibitors in thyroid cancer. Crit Rev Oncol Hematol. 2015;93(1):60-73.

3. Ambros V. The functions of animal microRNAs. Nature. 2004;431(7006): 350-355.

4. Bartel DP. MicroRNAs: genomics, biogenesis, mechanism, and function. Cell. 2004;116(2):281-297.

5. Kusenda B, Mraz M, Mayer J, Pospisilova S. MicroRNA biogenesis, functionality and cancer relevance. Biomed Pap Med Fac Univ Palacky Olomouc Czech Repub. 2006;150(2):205-215.

6. Mraz M, Pospisilova S, Malinova K, Slapak I, Mayer J. MicroRNAs in chronic lymphocytic leukemia pathogenesis and disease subtypes. Leuk Lymphoma. 2009;50(3):506-509.

7. Guo Z, Zhao C, Wang Z. MicroRNAs as ideal biomarkers for the diagnosis of lung cancer. Tumour Biol. 2014;35(10):10395-10407.

8. Lv J, Xu L, Xu Y, et al. [Expression of MiRNA-221 in non-small cell lung cancer tissues and correlation with prognosis]. Zhongguo Fei $\mathrm{Ai}$ Za Zhi. 2014;17(3):221-225.

9. Schena FP, Serino G, Sallustio F. MicroRNAs in kidney diseases: new promising biomarkers for diagnosis and monitoring. Nephrol Dial Transplant. 2014;29(4):755-763.

10. Zhang K, Zhang Y, Liu C, Xiong Y, Zhang J. MicroRNAs in the diagnosis and prognosis of breast cancer and their therapeutic potential (review). Int J Oncol. 2014;45(3):950-958.

11. Li Q, Liu L, Li W. Identification of circulating microRNAs as biomarkers in diagnosis of hematologic cancers: a meta-analysis. Tumour Biol. 2014;35(10):10467-10478.

12. Hughes L, Ruth K, Rebbeck TR, Giri VN. Genetic variation in IL-16 miRNA target site and time to prostate cancer diagnosis in AfricanAmerican men. Prostate Cancer Prostatic Dis. 2013;16(4):308-314.

13. Pallante P, Battista S, Pierantoni GM, Fusco A. Deregulation of microRNA expression in thyroid neoplasias. Nat Rev Endocrinol. 2014; 10(2):88-101.

14. Dettmer M, Perren A, Moch H, Komminoth P, Nikiforov YE, Nikiforova MN. Comprehensive MicroRNA expression profiling identifies novel markers in follicular variant of papillary thyroid carcinoma. Thyroid. 2013;23(11):1383-1389.

15. Huang Y, Liao D, Pan L, et al. Expressions of miRNAs in papillary thyroid carcinoma and their associations with the BRAFV600E mutation. Eur J Endocrinol. 2013;168(5):675-681.

16. Calin GA, Dumitru CD, Shimizu M, et al. Frequent deletions and down-regulation of micro-RNA genes miR15 and miR16 at 13q14 in chronic lymphocytic leukemia. Proc Natl Acad Sci U S A. 2002;99(24): 15524-15529.

17. Klein U, Lia M, Crespo M, et al. The DLEU2/miR-15a/16-1 cluster controls B cell proliferation and its deletion leads to chronic lymphocytic leukemia. Cancer Cell. 2010;17(1):28-40.

18. Cimmino A, Calin GA, Fabbri M, et al. miR-15 and miR-16 induce apoptosis by targeting BCL2. Proc Natl Acad Sci USA. 2005;102(39): 13944-13949.

19. Wang L, Qian L, Li X, Yan J. MicroRNA-195 inhibits colorectal cancer cell proliferation, colony-formation and invasion through targeting CARMA3. Mol Med Rep. 2014;10(1):473-478. 
20. Xu T, Zhu Y, Xiong Y, et al. MicroRNA-195 suppresses tumorigenicity and regulates G1/S transition of human hepatocellular carcinoma cells. Hepatology. 2009;50(1):113-121.

21. Li D, Zhao Y, Liu C, et al. Analysis of MiR-195 and MiR-497 expression, regulation and role in breast cancer. Clin Cancer Res. 2011; 17(7):1722-1730.

22. Wellbrock C, Karasarides M, Marais R. The RAF proteins take centre stage. Nat Rev Mol Cell Biol. 2004;5(11):875-885.

23. McKay MM, Morrison DK. Integrating signals from RTKs to ERK/ MAPK. Oncogene. 2007;26(22):3113-3121.

24. McCubrey JA, Steelman LS, Chappell WH, et al. Roles of the Raf/ $\mathrm{MEK} / \mathrm{ERK}$ pathway in cell growth, malignant transformation and drug resistance. Biochim Biophys Acta. 2007;1773(8):1263-1284.

25. Steelman LS, Chappell WH, Abrams SL, et al. Roles of the Raf/MEK/ ERK and PI3K/PTEN/Akt/mTOR pathways in controlling growth and sensitivity to therapy-implications for cancer and aging. Aging (Albany NY). 2011;3(3):192-222.

26. Hwang YH, Choi JY, Kim S, et al. Over-expression of c-raf-1 protooncogene in liver cirrhosis and hepatocellular carcinoma. Hepatol Res. 2004;29(2):113-121.

27. Chen C, Ridzon DA, Broomer AJ, et al. Real-time quantification of microRNAs by stem-loop RT-PCR. Nucleic Acids Res. 2005;33(20): e179.

28. Pfaffl MW. A new mathematical model for relative quantification in real-time RT-PCR. Nucleic Acids Res. 2001;29(9):e45.

29. Qian B, Nag SA, Su Y, et al. miRNAs in cancer prevention and treatment and as molecular targets for natural product anticancer agents. Curr Cancer Drug Targets. 2013;13(5):519-541.

30. Oberman B, Khaku A, Camacho F, Goldenberg G. Relationship between obesity, diabetes and the risk of thyroid cancer. Am J Otolaryngol. 2015;36(4):535-541.

31. Han B, Cui H, Kang L, et al. Metformin inhibits thyroid cancer cell growth, migration, and EMT through the mTOR pathway. Tumour Biol. 2015;36(8):6295-6304.

32. Chong H, Vikis HG, Guan KL. Mechanisms of regulating the Raf kinase family. Cell Signal. 2003;15(5):463-469.

33. Fang JY, Richardson BC. The MAPK signalling pathways and colorectal cancer. Lancet Oncol. 2005;6(5):322-327.

34. Lai EC. Micro RNAs are complementary to $3^{\prime}$ UTR sequence motifs that mediate negative post-transcriptional regulation. Nat Genet. 2002; 30(4):363-364.

35. Ma Y, Qin H, Cui Y. MiR-34a targets GAS1 to promote cell proliferation and inhibit apoptosis in papillary thyroid carcinoma via PI3K/Akt/ Bad pathway. Biochem Biophys Res Commun. 2013;441(4):958-963.
36. Geraldo MV, Yamashita AS, Kimura ET. MicroRNA miR-146b-5p regulates signal transduction of TGF-beta by repressing SMAD4 in thyroid cancer. Oncogene. 2012;31(15):1910-1922.

37. Liu L, Wang J, Li X, et al. MiR-204-5p suppresses cell proliferation by inhibiting IGFBP5 in papillary thyroid carcinoma. Biochem Biophys Res Commun. 2015;457(4):621-626.

38. Bonci D, Coppola V, Musumeci M, et al. The miR-15a-miR-16-1 cluster controls prostate cancer by targeting multiple oncogenic activities. Nat Med. 2008;14(11):1271-1277.

39. Wang X, Wang J, Ma H, Zhang J, Zhou X. Downregulation of miR-195 correlates with lymph node metastasis and poor prognosis in colorectal cancer. Med Oncol. 2012;29(2):919-927.

40. Brenner B, Hoshen MB, Purim O, et al. MicroRNAs as a potential prognostic factor in gastric cancer. World J Gastroenterol. 2011;17(35): 3976-3985.

41. Luo Q, Wei C, Li X, et al. MicroRNA-195-5p is a potential diagnostic and therapeutic target for breast cancer. Oncol Rep. 2014;31(3): 1096-1102.

42. Yang Y, Li M, Chang S, et al. MicroRNA-195 acts as a tumor suppressor by directly targeting Wnt3a in HepG2 hepatocellular carcinoma cells. Mol Med Rep. 2014;10(5):2643-2648.

43. Itesako T, Seki N, Yoshino H, et al. The microRNA expression signature of bladder cancer by deep sequencing: the functional significance of the miR-195/497 cluster. PLoS One. 2014;9(2):e84311.

44. Liu B, Qu J, Xu F, et al. MiR-195 suppresses non-small cell lung cancer by targeting CHEK1. Oncotarget. 2015;6(11):9445-9456.

45. Li D, Jian W, Wei C, et al. Down-regulation of miR-181b promotes apoptosis by targeting CYLD in thyroid papillary cancer. Int J Clin Exp Pathol. 2014;7(11):7672-7680.

46. Zhou Y, Tian L, Wang X, et al. MicroRNA-195 inhibits non-small cell lung cancer cell proliferation, migration and invasion by targeting MYB. Cancer Lett. 2014;347(1):65-74.

47. Wang X, Wang Y, Lan H, Li J. MiR-195 inhibits the growth and metastasis of NSCLC cells by targeting IGF1R. Tumour Biol. 2014;35(9): $8765-8770$

48. Guo H, Li W, Zheng T, Liu Z. MiR-195 targets HDGF to inhibit proliferation and invasion of NSCLC cells. Tumour Biol. 2014;35(9): 8861-8866.

49. Ouyang M, Li Y, Ye S, et al. MicroRNA profiling implies new markers of chemoresistance of triple-negative breast cancer. PLoS One. 2014; 9(5):e96228.

50. Yang G, Wu D, Zhu J, et al. Upregulation of miR-195 increases the sensitivity of breast cancer cells to Adriamycin treatment through inhibition of Raf-1. Oncol Rep. 2013;30(2):877-889.
OncoTargets and Therapy

\section{Publish your work in this journal}

OncoTargets and Therapy is an international, peer-reviewed, open access journal focusing on the pathological basis of all cancers, potential targets for therapy and treatment protocols employed to improve the management of cancer patients. The journal also focuses on the impact of management programs and new therapeutic agents and protocols on

\section{Dovepress}

patient perspectives such as quality of life, adherence and satisfaction The manuscript management system is completely online and includes a very quick and fair peer-review system, which is all easy to use. Visit http://www.dovepress.com/testimonials.php to read real quotes from published authors. 